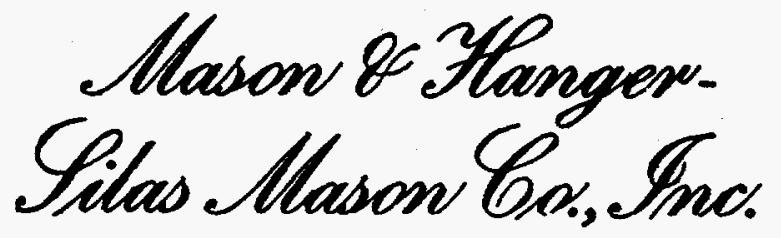

ENGINEERS AND CONTRACTORS

SINCEIS2T

Pentex Plont

\title{
EXPLOSIVE PERForMANCE
}

SANL 712-004

Paul E. Kramer

Apri1, May, June 1970

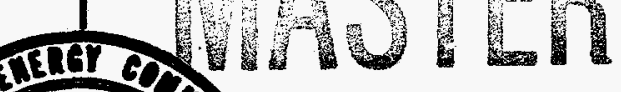

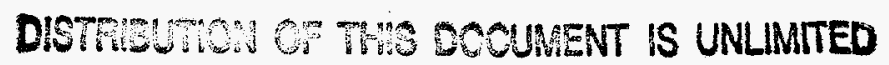
8 


\section{DISCLAMIER}

Portions of this document may be illegible in electronic image products. Images are produced from the best available original document. 


\section{Explosive Performance}

Paul E. Kramer

April, May, June 1970

SANL 712-004

The determination of detonation velocity, shock sensitivity, impact sensitivity, etc.; and the acquisition of high precision one-dimensional hydrodynamic data for use in establishing detonation product equations of state, performance of explosives, etc.

\section{ABSTRACT}

A three-shot wedge test series was fired with $R X-08-A Z$. In terms of transmitted pressure, its sensitivity is comparable to that of LX-09-0.

An exponential model was studied as a possible substitute for polynomials in fitting cylinder test data.

\section{DISCLAIMER}

This report was prepared as an account of work sponsored by an agency of the United States Government. Neither the United States Government nor any agency thereof, nor any of their employees, makes any warranty, express or implied, or assumes any legal liability or responsibility for the accuracy, completeness, or usefulness of any information, apparatus, product, or process disclosed, or represents that its use would not infringe privately owned rights. Reference herein to any specific commercial product, process, or service by trade name, trademark, manufacturer, or otherwise does not necessarily constitute or imply its endorsement, recommendation, or favoring by the United States Government or any agency thereof. The views and opinions of authors expressed herein do not necessarily state or reflect those of the United States Government or any agency thereof. 
Wedge Test

A three shot wedge test series was fired with $R X-08-A Z$. The wedges were machined from Skid Test Piece \#3, at a density of $1.820 \mathrm{gm} / \mathrm{cc}$. The average observed detonation velocity was $8.6 \mathrm{~mm} / \mu \mathrm{sec}$.

Wedge Tests with $R X-08-A Z$

\begin{tabular}{|c|c|c|c|c|c|c|c|}
\hline $\begin{array}{l}\text { Shot } \\
\text { No. } \\
\end{array}$ & $\begin{array}{l}\text { Booster } \\
\text { (one-inch) } \\
\end{array}$ & Attenuator (s) & $\begin{array}{c}P_{i} \\
(K b a r) \\
\end{array}$ & $\begin{array}{c}\mathrm{P}_{\mathrm{t}} \\
(\mathrm{Kb} \mathrm{a} r)\end{array}$ & $\begin{array}{l}\text { Distance } \\
\text { to Det- } \\
\text { onation } \\
(\mathrm{mm}) \\
\end{array}$ & $\begin{array}{l}\text { Time to } \\
\text { Detona- } \\
\text { tion (mm) }\end{array}$ & $\begin{array}{l}\text { Excess } \\
\text { Transit } \\
\text { Time } \\
\text { (usec) }\end{array}$ \\
\hline 1 & $\mathrm{CB}-3$ & Brass - 1" & 244 & 82 & 2.6 & .57 & .27 \\
\hline 2 & Baratol & Brass - $\frac{3}{2} "$ & 179 & 58 & 5.2 & 1.21 & .61 \\
\hline 3 & Baratol & $\begin{array}{l}\text { Plexiglas }-\frac{1}{2} " \\
\text { Brass - } \frac{11}{2} "\end{array}$ & 149 & 47 & 7,1 & 1.76 & .94 \\
\hline
\end{tabular}

It is customary to express shock sensitivity in terms of transmitted pressure and excess transit time. When $R X-08-A Z$ is compared to $L X-09-0^{1}$ in this context, they display essentially the same sensitivity. But, from a practical standpoint, some other factors would appear to be worthy of note. For instance, LX-09-0 and RX-08-AZ display about the same excess transit times, but a plot of transmitted pressure against distance to detonation indicates that $\mathrm{RX}-08-\mathrm{AZ}$ is less sensitive than LX-09-0 from a spatial viewpoint.

${ }_{1}$ Kramer, P. E., Quarterly Report on Explosive Performance for Oct., Nov., Dec., 1968. 
A greater difference becomes apparent when incident pressure is considered instead of transmitted pressure. Of course, the relation between incident and transmitted pressure depends upon the donor material but since all these shots employed a brass donor plate, the comparison is valid. Since a given incident pressure resulted in appreciably less transmitted pressure in $R X-08-A Z$, then in terms of incident pressure, $R X-08-A Z$ is less shock sensitive than LX-09-0 (see figure).

\section{Cylinder Test Analys is}

Plots of curve-fit results for cylinder tests have revealed oscillations in the velocity-expansion curve which can be attributed to the polynomial model. (This may result from single-precision limitation on the IBM 360.) Attempts were made to apply a model of the form $T=A_{1}+A_{2} R+A_{3} e^{A_{4} R}$ to the $R-T$ data beyond $2 \mathrm{~mm}$ (one-inch diameter test). This model, of course, was free from the oscillations inherent in polynomials but was incapable of suitably describing expansion between 2 and $14 \mathrm{~mm}$. At present, polynomials are still employed but generally limited to the seventh degree. 
D-4

Fig. 1

Excess Transit Time Versus Incident and Transmitted Pressure

(Brass Donor for Each Shot)

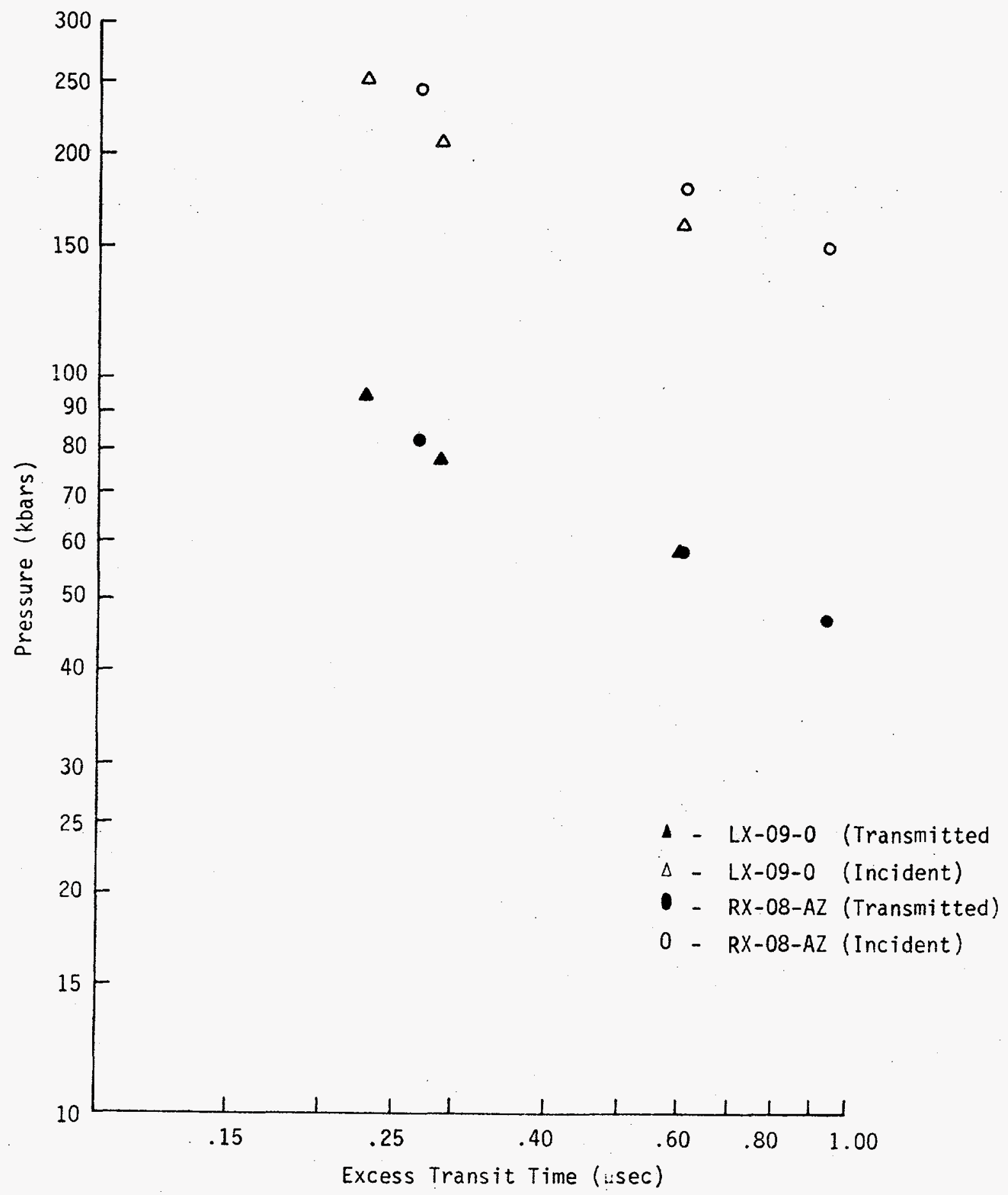

